\title{
Corporate Governance and Financial Reporting Quality: Preliminary Evidence from Saudi Arabia
}

http://doi.org/10.21272/fmir.4(1).109-116.2020

Sarah Al-Khonain, ORCID: https://orcid.org/0000-0002-3405-8038

Master of Science in Accountancy, Accountant, Ministry of Justice, Saudi Arabia

Khalid Al-Adeem, ORCID: https://orcid.org/0000-0002-1727-4492

$\mathrm{PhD}$, Associate Professor of Accounting, Accounting Department, College of Business Administration, King Saud University, Saudi Arabia

\begin{abstract}
The investment climate in the country depends largely on the level of confidence of potential investors, which actualizes the need to provide transparent and quality financial reporting to economic entities. Powerful corporations that have established an effective corporate governance mechanism are able to provide high competitive advantage over the long term, contributing to their financial and economic stability. The purpose of the article is to determine the impact of corporate governance mechanisms on the quality of a company's financial statements. The corporate governance rules in force in Saudi Arabia were developed in 2006, then revised twice in 2009 and 2015, and only finally approved in 2017. The survey was based on the results of an electronic survey of 56 Saudi financial analysts selected from their LinkedIn profiles (financial analysts were selected by respondents because they play a significant role in the capital markets and are users of financial statements). The author points out that the objectivity of the survey results can be enhanced by expanding the sample of survey participants. The questionnaire contained 11 questions about corporate governance and its contribution to improving the quality of the financial statements of the respective companies. The results of the survey have empirically confirmed that corporate governance is a factor contributing to improving the quality of financial reporting and, consequently, increasing foreign investment inflows, so compliance with the new corporate governance rules is extremely important for Saudi Arabia corporations. Improvements in corporate governance mechanisms are perceived by members of boards of directors, audit committees, and internal audit departments as one of the main factors in improving the quality of financial reporting.
\end{abstract}

Keywords: corporate governance; Financial Statements; financial analysts; transparency of reporting; investors; Saudi Arabia.

JEL Classification: M41, M48, G2, G3, K2.

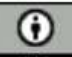

This work is licensed under a Creative Commons Attribution 4.0 International License

Cite as: Al-Khonain, S., Al-Adeem, K. (2020). Corporate Governance and Financial Reporting Quality: Preliminary Evidence from Saudi Arabia. Financial Markets, Institutions and Risks, 4(1), 109-116. http://doi.org/10.21272/fmir.4(1).109-116.2020.

(C) The Authors, 2020. This article is published with open access at Sumy State University.

\section{Introduction}

Interests of corporation managers and directors often differ from those of owners (Berle and Means, 1932). Agency problems arise when executives make investment, financing, and operating decisions in their own interests in ways that are not aligned with stakeholders' interests. Giant corporations such as Enron, WorldCom, and Tyco witnessed bankruptcies in the early 2000s, which were associated with fraud in corporate reporting. Lack of integrity in the executive management may lead to their prioritizing their self-interests while neglecting stakeholders' interest. Managing earnings through fraudulent reporting or other means with the intent of affecting share prices for their gain might come at the expense of other stakeholders, particularly parties that finance the corporation (Ioana and Mariana, 2014). These factors highlight the need for more regulations and governance. To mitigate such agency problems, corporate governance has been implemented as a monitoring system in various organizations (Watson and Hirsch, 2010). 
Corporate governance can be defined as a set of control mechanisms that an organization adopts to prevent or constraint potential self-benefiting managers from engaging in activities that harm the interests of stakeholders and shareholders (Larcker and Tayan, 2011). The laws, policies, and directives introduced by corporate governance affect a corporation's way of controlling and monitoring (Buallay et al., 2017). It also enhances transparence and clarity in the relationship between the corporation and its stakeholders to obviate conflicting interests (Buallay et al., 2017). Corporations that have established a strong corporate governance mechanism can enhance their corporate value in the long term and secure competitive advantages that contribute to increasing their social wealth (Watson and Hirsch, 2010). According to a survey by McKinsey \& Company (2002), investors place corporate governance at par with financial indicators when evaluating investment decisions; in fact, many investors are willing to pay a premium for a well-governed company.

Corporate governance is significant and relevant for corporations that prioritize foreign investment. Analyzing mutual funds that hold equity in 37 countries, Das (2014) concludes that corporate governance practices play a role in attracting foreign investors by reducing information asymmetry. Corporation owners can receive only second-hand information as executive managers are directly and closely involved in day-to-day operations of the corporation, and thus, they suffer from lack of information regarding the extent to which managers are performing their job in an optimal manner and in the best interests of the corporation (Watson and Hirsch, 2010). Since information asymmetry is an identifying characteristic of the corporate model for business, an internal "watchdog" is a necessary mechanism for shareholders and parties, on which the shareholders can depend to make informed decisions. Saudi Arabia recently issued its Vision 2030 initiative, which highlights foreign investment as an important objective. Building trust and restoring confidence in financial reporting is of significance in attracting international investors. Corporate governance can help establish confidence in a country's capital market (Ahmed and Hamdan, 2015). This study focuses on corporate governance's contribution to enhancing the quality of financial reporting. Specifically, it empirically investigates financial analysts' perceptions in Saudi Arabia to determine the extent to which corporate governance enhances the quality of financial reporting. The rest of the paper proceeds as follows: the next section reviews the relevant literature. The third section presents the methods used to collect data. The fourth section discusses the results, and the last section concludes with the limitations of the study and suggestions for future research.

\section{Literature Review}

Humans tend to take advantage of ineffectual prospects (Jensen and Meckling, 1994); similarly, cooperation between corporate management and the owner encourages them to undertake actions for self-interest at the cost of the other party's interests (Jensen and Meckling, 1976). For example, directors might be involved in embezzling from corporate assets for their personal gain (Watson and Hirsch, 2010). Corruption in a corporate model can harm the corporation by encouraging misbehavior by insiders to serve their own interests. In fact, deficiency or absence of corporate governance was one of the main causes of the collapse of giant corporations such as Enron and WorldCom (Umm Kulthum et al., 2014). These highlight the need for effective governance. Arguably, corporate governance can be a mitigating devise that protects the interests of stakeholders and users of corporate reporting (Merag and Adam [معراج و آدم], 2012; Hermalin and Weisbach, 1998; 2003).

In this regard, the Organization for Economic Co-operation and Development (OECD) aimed at designing policies to improve economic welfare around the globe. The OECD has adopted six principles for corporate governance: The first principle is to ensure the basis for an effective corporate governance framework. The second principle is concerned with the rights of shareholders and key ownership functions. The third principle emphasizes the equitable treatment of shareholders. The fourth principle is related to the role of stakeholders in corporate governance. The fifth principle focuses on disclosure and transparency, and the last principle details the responsibilities of the board (OECD, 2004).

Several countries have implemented these principles for effective corporate governance to reduce the conflicts of interest in corporations and achieve a workable corporate model. In Jordan, Al Ramahi et al. (2014) find an increase in the application of these principles in the listed companies on the first market in the Amman Stock Exchange. Examining the consequences of the application of these principles on the quality of financial reporting in private universities in Jordan, Alweshah and Shaheen ([الوشاح وشاهين], 2017) report that the aforementioned principles contribute significantly to enhancing the quality of financial reporting. Another study on Jordanian listed industrial companies document a relationship between the six principles of corporate governance and quality of financial reporting (Al-Sufy et al., 2013). Empirical evidence also suggests that the 
six principles contributed to enhancing the accounting disclosure and the quality of financial reporting of listed companies in the Khartoum Stock Exchange (Al-Qusi [القوصي], 2015). Analyzing the Tehran Stock Exchange, Salehi et al. (2017) report a significant relationship between corporate governance and the disclosure quality of financial statements of corporations. According to accountants and financial analysts in the Malaysian banking sector, better quality of financial reporting can be achieved by separating the board leadership's roles, increasing the proportion of independent non-executive directors, minimizing ownership by directors, and increasing the board size (Htay et al., 2013). In Egypt, Albaz ( [الباز], 2012) report a direct correlation between the application of corporate governance principles (disclosure and transparency) and the quality of financial reporting. However, empirical findings in Iraq point to a negative relationship between the quality of financial reporting and disclosure, as well as between the seniority of shareholders on the boards of directors and the boards' efficiency (Alfadl [الفضل], 2014).

\section{Shedding Light on the Saudi Capital Market}

Although the corporate governance structure in Saudi Arabia is considered better than other countries in the Middle East (Al-Aali et al., 2014: 1332), the efficiency of the Saudi capital market is low (Al-Adeem [العديم], 2017; see also Al-Salman, 2007; Alzahrani, 2010; Alabaas [آل عباس], 2008), and accordingly, most studies analyzing the effectiveness of corporate governance in Saudi Arabia assume weak efficiency (Al-Adeem and Al-Sogair, 2019). However, the trends observed in the Saudi capital market are no different than those in most other countries. Managers of publicly traded corporations are incentivized to manage corporate earnings by increasing their compensation, leveraging the capital structure, and smoothing corporate income profit (Habbash and Alghamdi, 2015). Corporate governance and the structure of ownership both affect voluntary disclosure in annual reports of Saudi listed firms (Habbash, 2014). Government ownership also affects corporate governance and corporate disclosure in Saudi corporations (Al-Janadi et al., 2016). In general, institutional ownership (Hamdan and Al-Sartawi, 2013) and government ownership (Al-Janadi et al., 2016) influence various dimensions of corporate governance. Whereas government ownership affects governorate disclosure and governance. Surprisingly, Al-Shabeeb and Al-Adeem ([الثبيب والعدير], 2019) document that earnings management may not be perceived as entirely unethical by some stakeholders in Saudi Arabianamely, the users of financial statements. Moreover, whether such users perceive an enhancement in the quality of corporate reporting as due to corporate governance is unknown. Thus, examining the perceptions of financial analysts as users of corporate reporting regarding the quality of such reporting will add to our knowledge.

This study contributes to the body of accounting knowledge by investigating the perception of financial statement users regarding the enhancement of corporate reporting quality after Saudi Arabia issued its Corporate Governance Regulations - launched in 2006 and then later revised twice in 2009 and 2015. Furthermore, in 2015, the new Companies' Law was enacted, encouraging yet another update to the Corporate Governance Regulations, which was finally implemented in 2017. Two empirical studies, however, document that there was no concurrent improvement in "firms' operational and financial performance in the listed companies in Saudi stock exchange" (Buallay et al., 2017: 94) nor in the effectiveness of corporate governance in monitoring executive management (Al-Adeem and Al-Sogiar, 2019).

\section{Research Method}

Financial analysts were selected as the respondents because they play a significant role in capital markets (Fogarty and Rogers, 2005). Furthermore, they also serve as users of financial statements (Horngren, 1978), which is suitable for this study. A published survey developed by Ibrahim and Makiah ([ابر هيم ومكية], 2011) was employed for data collection. The survey included 11 items on corporate governance and its contribution to enhancing the quality of financial reporting. Necessary modifications were made to the instrument to make it suitable for the Saudi Arabian context: first, we changed the point scale titled (agree somewhat) to (I do not know). Second, the questionnaire was translated from Arabic to English and then made available for participants in both languages. The Arabic version was used because it is the main language in Saudi Arabia and the intent was to reach as many respondents as possible. The English version was used because many financial analysts in Saudi Arabia use English for communication. Before issuing the questionnaire to participants, the translated documents were reviewed by two accounting academics. Electronic questionnaires were prepared and a pilot study conducted with graduate students who possess research knowledge. All issues raised by the pilot study participants regarding the content were addressed. Finally, we identified financial analysts in Saudi Arabia through information on their LinkedIn profiles, and then sent the questionnaire electronically via email or LinkedIn. 


\section{Research Findings}

A total of 56 financial analysts responded to the survey. Table (1) shows that about $50 \%$ of the respondents hold a Bachelor's degree, $46 \%$ hold a Master's degree, and 2\% each hold a higher diploma or a $\mathrm{PhD}$ degree.

Table 1. Distribution of the Sample by Academic Qualification

\begin{tabular}{|l|c|c|}
\hline & Frequency & Ratio \\
\hline Bachelor's degree & 28 & $50 \%$ \\
\hline Higher diploma & 1 & $2 \%$ \\
\hline Master's degree & 26 & $46 \%$ \\
\hline Ph.D. & 1 & $2 \%$ \\
\hline Total & 56 & $100 \%$ \\
\hline
\end{tabular}

Source: by the authors.

Table 2 indicates that most respondents (70\%) have less than 10 years of work experience. About $16 \%$ have less than 15 years of experience, while $13 \%$ have experience of 15 to 20 years. Only $2 \%$ have more than 20 years of experience.

Table 2. Distribution of the Sample by Years of Experience

\begin{tabular}{|l|c|c|}
\hline & Frequency & Ratio \\
\hline Less than 10 years & 39 & $70 \%$ \\
\hline From 10 to 15 years & 9 & $16 \%$ \\
\hline From 15 to 20 years & 7 & $13 \%$ \\
\hline More than 20 years & 1 & $2 \%$ \\
\hline Total & 56 & $100 \%$ \\
\hline
\end{tabular}

Source: by the authors.

Table (3) presents the values of the scale points of the questionnaire and the five class intervals, which were calculated as follows: Class width $=$ (the maximum value - the minimum value)/the number of the scale points. By this formula, we obtained a class width of 0.80 .

Table 3. Weighted Values of the Point Scales and Class Intervals

\begin{tabular}{|l|c|c|c|c|c|}
\hline & $\begin{array}{l}\text { Strongly } \\
\text { disagree }\end{array}$ & Disagree & Do not know & Agree & Strongly agree \\
\hline Values of the scale points & 1 & 2 & 3 & 4 & 5 \\
\hline Class intervals & $1-1.80$ & $1.81-2.60$ & $2.61-3.40$ & $3.41-4.20$ & $4.21-5$ \\
\hline
\end{tabular}

Source: Al-Amri (2011:17 [العمري]).

Table (4) shows the descriptive statistics of the data. The averages of the responses are ranked in descending order. The mean of item (4) is 4.48 , with a standard deviation of 0.69 . The maximum score for this item is 5 , while the minimum score is 2 . The mean is within the "strongly agree" class interval, which indicates that implementation of governance mechanisms of the board of directors, audit committees, internal audit departments, and professional rules of practice is perceived as the leading cause of enhancement in the quality of financial reporting. The mean of item (1) is 4.46, with a standard deviation of 0.69. Again, the maximum score is 5 and the minimum score is 2 . The mean falls within the "strongly agree" class interval, which indicates that the sampled financial analysts regard adoption of corporate governance as reinforcing confidence in accounting information by achieving the quality comprehensively defined by information based on legal, professional, technical, and regulatory criteria. The mean of item (3) is 4.39 , with a standard deviation of 0.80 . The mean lies within the "strongly agree" class interval. Thus, we can infer that the respondents consider the adoption of corporate governance to help in creating a transparent and credible environment. The mean of item (2) is 4.36 , with a standard deviation of 0.72 . Thus, the respondents strongly agree that participants' confidence in the capital markets is reinforced through the adoption of corporate governance. The mean of item (5) is 4.32, with a standard deviation of 0.94 . Thus, respondents agree that the adoption of corporate governance strongly enhances confidence in the information of financial statements. With means of 4.16, 4.04, 4, 3.88, 3.66, and 3.55 , respectively, the respondents agreed on items (6), (7), (8), (9), (11) and (10) - that these factors enhance the quality of financial reporting. Thus, the overall results suggest that the subjects perceive corporate governance to be a contributing factor to the enhancement of the quality of financial reporting. This result is 
further supported by the grand mean of the means of all the items, which is as high as 4.12. Graph (1) presents the distribution of responses to the survey questions; it clearly shows that many respondents "strongly agree" and "agree" to the questionnaire items.

Table 4. Descriptive Statistics for All Items

\begin{tabular}{|c|c|c|c|c|c|c|c|c|c|c|}
\hline Item & & $\begin{array}{l}\text { Strongly } \\
\text { Disagree }\end{array}$ & $\begin{array}{l}\text { Disagr } \\
\text { ee }\end{array}$ & $\begin{array}{l}\text { I don't } \\
\text { Know }\end{array}$ & Agree & $\begin{array}{c}\text { Strongly } \\
\text { Agree }\end{array}$ & Mean & $\mathrm{SD}$ & Max & Mini \\
\hline \multirow[t]{2}{*}{$\begin{array}{l}\text { 4) Implementing the } \\
\text { governance mechanisms of the } \\
\text { board of directors, audit } \\
\text { committees, internal audit } \\
\text { departments, and professional } \\
\text { rules of practice enhances the } \\
\text { quality of financial reporting. }\end{array}$} & Count & & 2 & & 23 & 31 & 4,48 & 0,69 & 5 & 2 \\
\hline & Ratio & & $4 \%$ & & $41 \%$ & $55 \%$ & & & & \\
\hline \multirow[t]{2}{*}{$\begin{array}{l}\text { 1) The adoption of corporate } \\
\text { governance reinforces } \\
\text { confidence in accounting } \\
\text { information by achieving the } \\
\text { quality comprehensively } \\
\text { defined in information based on } \\
\text { legal, professional, technical, } \\
\text { and regulatory criteria. }\end{array}$} & Count & & 2 & & 24 & 30 & 4,46 & 0,69 & 5 & 2 \\
\hline & Ratio & & $3.5 \%$ & & $43 \%$ & $53,5 \%$ & & & & \\
\hline \multirow[t]{2}{*}{$\begin{array}{l}\text { 3) The adoption of corporate } \\
\text { governance helps in creating a } \\
\text { transparent and credible } \\
\text { environment. }\end{array}$} & Count & & 2 & 5 & 18 & 31 & 4,39 & 0,80 & 5 & 2 \\
\hline & Ratio & & $4 \%$ & $9 \%$ & $32 \%$ & $55 \%$ & & & & \\
\hline \multirow[t]{2}{*}{$\begin{array}{l}\text { 2) The adoption of corporate } \\
\text { governance reinforces } \\
\text { participants confidence in } \\
\text { capital markets. }\end{array}$} & Count & & 2 & 2 & 26 & 26 & 4,36 & 0,72 & 5 & 2 \\
\hline & Ratio & & $4 \%$ & $4 \%$ & $46 \%$ & $46 \%$ & & & & \\
\hline \multirow[t]{2}{*}{$\begin{array}{l}\text { 5) Implementation of corporate } \\
\text { governance increases } \\
\text { confidence in financial } \\
\text { statements as it includes legal } \\
\text { and regulatory aspects and leads } \\
\text { to improvement in accounting } \\
\text { practices. }\end{array}$} & Count & 1 & 4 & & 22 & 29 & 4,32 & 0,94 & 5 & 1 \\
\hline & Ratio & $2 \%$ & $7 \%$ & & $39 \%$ & $52 \%$ & & & & \\
\hline \multirow[t]{2}{*}{$\begin{array}{l}\text { 6) Implementation of corporate } \\
\text { governance leads to the } \\
\text { establishment of legal criteria } \\
\text { that reflect the laws and } \\
\text { regulations of the corporation to } \\
\text { assess the quality of accounting } \\
\text { information. }\end{array}$} & Count & & 1 & 6 & 32 & 17 & 4,16 & 0,68 & 5 & 2 \\
\hline & Ratio & & $2 \%$ & $11 \%$ & $57 \%$ & $30 \%$ & & & & \\
\hline \multirow[t]{2}{*}{$\begin{array}{l}\text { 7) Implementation of corporate } \\
\text { governance leads to the } \\
\text { establishment of regulatory } \\
\text { criteria that reflect the current } \\
\text { regulations and control } \\
\text { techniques to assess the quality } \\
\text { of accounting information. }\end{array}$} & Count & & 5 & 4 & 31 & 16 & 4,04 & 0,85 & 5 & 2 \\
\hline & Ratio & & $9 \%$ & $7 \%$ & $55 \%$ & $29 \%$ & & & & \\
\hline \multirow[t]{2}{*}{$\begin{array}{l}\text { 8) Implementation of corporate } \\
\text { governance leads to the } \\
\text { establishment of professional } \\
\text { criteria that reflect the extent to } \\
\text { which accounting and auditing } \\
\text { standards are applied to assess } \\
\text { the quality of accounting } \\
\text { information. }\end{array}$} & Count & & 4 & 8 & 28 & 16 & 4,00 & 0,85 & 5 & 2 \\
\hline & Ratio & & $7 \%$ & $14 \%$ & $50 \%$ & $29 \%$ & & & & \\
\hline
\end{tabular}


Table 4 (cont.). Descriptive Statistics for All Items

\begin{tabular}{|c|c|c|c|c|c|c|c|c|c|c|}
\hline Item & & $\begin{array}{l}\text { Strongly } \\
\text { Disagree }\end{array}$ & $\begin{array}{c}\text { Disagr } \\
\text { ee }\end{array}$ & $\begin{array}{l}\text { I don't } \\
\text { Know }\end{array}$ & Agree & $\begin{array}{l}\text { Strongly } \\
\text { Agree }\end{array}$ & Mean & SD & Max & Mini \\
\hline \multirow{2}{*}{$\begin{array}{l}\text { 9) Implementation of } \\
\text { corporate governance leads to } \\
\text { the establishment of technical } \\
\text { criteria that reflect the } \\
\text { availability of accounting } \\
\text { information characteristics to } \\
\text { assess the quality of } \\
\text { accounting information. }\end{array}$} & Count & & 5 & 9 & 30 & 12 & 3,88 & 0,85 & 5 & 2 \\
\hline & Ratio & & $9 \%$ & $16 \%$ & $54 \%$ & $21 \%$ & & & & \\
\hline \multirow{2}{*}{ 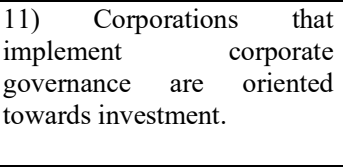 } & Count & 3 & 7 & 14 & 14 & 18 & 3,66 & 1,21 & 5 & 1 \\
\hline & Ratio & $5 \%$ & $13 \%$ & $25 \%$ & $25 \%$ & $32 \%$ & & & & \\
\hline \multirow{2}{*}{$\begin{array}{ll}\text { 10) Implementation of } \\
\text { corporate governance leads to } \\
\text { the establishment of } \\
\text { comprehensive criteria to } \\
\text { assess the quality of } \\
\text { accounting information. }\end{array}$} & Count & & 12 & 8 & 29 & 7 & 3,55 & 0,97 & 5 & 2 \\
\hline & Ratio & & $21 \%$ & $14 \%$ & $52 \%$ & $13 \%$ & & & & \\
\hline
\end{tabular}
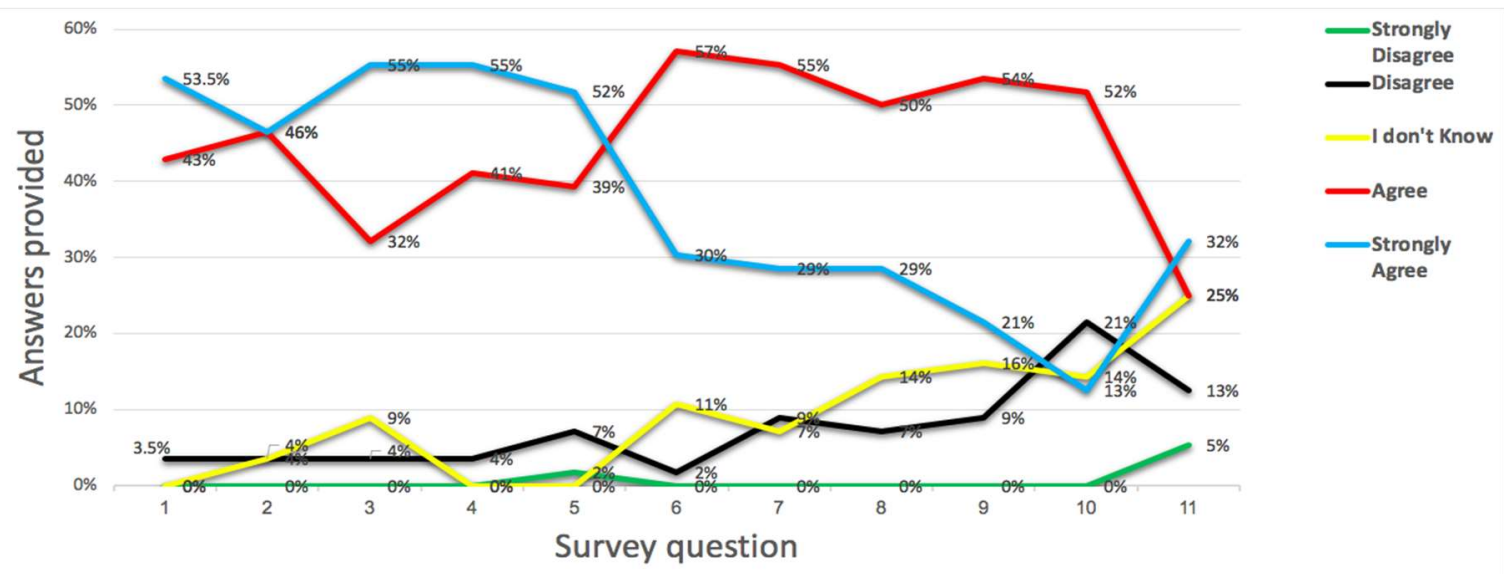

Figure 1. Distribution of Items

Source: by the authors.

\section{Conclusion}

Saudi Arabia's Vision 2030 considers attracting foreign investment an important objective. For this, confidence in the financial reporting of publicly traded corporations needs to be boosted. This study empirically investigated whether corporate governance contributes to the enhancement of the quality of financial reporting. We assessed the perception of financial analysts to examine the value added of corporate governance to the quality of corporate reporting, as perceived by users of financial statements. We found that corporate governance is a contributing factor to the enhancement of the quality of financial reporting. However, our study is limited in its sample size: findings from a small sample may not be generalizable beyond the respondents. Therefore, future studies should investigate this research issue with more participants. Researchers should also examine the extent to which Saudi corporations comply with the new corporate governance regulations and the impact of corporate governance regulations on foreign investment in Saudi Arabia.

\section{Acknowledgment}

We thank Dr. Abdulaziz Alwathnani, a professor of accounting at Alfaisal University and Dr. Mosaab Aljuaid, a professor of accounting at Umm Al-Qura University for evaluating the translation of the questionnaire. 
Financial Markets, Institutions and Risks, Volume 4, Issue 1, 2020 ISSN (online) - 2521-1242 ISSN (print) - 2521-1250

\section{References}

1. Ahmed, E., \& Hamdan, A. (2015). The impact of corporate governance on firm performance: Evidence from Bahrain Bourse. International Management Review, 11(2), 21-37. Available at: https://www.researchgate.net/publication/299991166_The_Impact_of_Corporate_Governance_on_Firm Performance Evidence From_Bahrain_Bourse

2. Ahmad, E., Ullah, M. A., \& Arfeen, M. I. (2012). Does corruption affect economic growth? Latin American Journal of Economics, 49(2), 277-305. Available at: https://www.jstor.org/stable/41959246

3. Al-Adeem, K. R. (العديم). (2017). Significance of announcing auditor switch by corroborations in Saudi Arabia: Analysis of professional and legal requirements. Accounting Thought Journal, 21(issue 2 part 1), 223-262. Available at: https://scholar.google.com/citations?user=q40JA78AAAAJ\&hl=en\#d=gs md cita-d\&u=\%2 Fcitations\%3Fview op\%3Dview citation\%26hl\%3Den\%26user\%3Dq4oJA78AAAAJ\% 26citation_for_view\% 3Dq4oJA78AAAAJ\%3AzYLM7Y9cAGgC\%26tzom\%3D-180

4. Al-Adeem, K., \& Al-Sogair, I. Y. (2019). Effectiveness of the board of directors in monitoring executive management: Preliminary evidence from Saudi Arabia. Journal of Governance \& Regulation, 8(3), 72-82. Available at: https://scholar.google.com/citations?user=q40JA78AAAAJ\&hl=en\#d=gs md cita$\mathrm{d} \& \mathrm{u}=\% 2 \mathrm{Fcitations} \% 3 \mathrm{Fview}$ op $\% 3$ Dview_citation $\% 26 \mathrm{hl} \% 3 \mathrm{Den} \% 26 \mathrm{user} \% 3 \mathrm{Dq} 4 \mathrm{oJA} 78 \mathrm{AAAAJ} \%$ 26citation for_view\%3Dq40JA78AAAAJ\%3A_FxGoFyzp5QC\%26tzom\%3D-180

5. Al-Qusi, K. (القوصي). (2015). The role of corporate governance in accounting disclosure and financial reporting quality: case study of companies listed in Khartoum Stock Exchange. (Doctoral dissertation). Retrieved from Dar Almandumah for Dissertations. (789218). Available at: http://www.irbis-nbuv.gov.ua/cgibin/irbis_nbuv/cgiirbis_64.exe?C21COM=2\&I21DBN=UJRN\&P21DBN=UJRN\&IMAGE_FILE_DOWNL $\underline{\mathrm{OAD}=1 \& \text { Image file name }=\mathrm{PDF} / \mathrm{imfi} 2016 \quad 13 \quad 4 \quad 8 . \mathrm{pdf}}$

6. Al-Janadi, Y., Abdul Rahman, R., \& Alazzani, A. (2016). Does government ownership affect corporate governance and corporate disclosure? Evidence from Saudi Arabia. Managerial Auditing Journal, 31(8-9), 871890. Available at: https://www.researchgate.net/publication/308575226 Does_government ownership_affect corporate governance andcorporate disclosure Evidence from Saudi_Arabia

7. Al Ramahi, N., Alaboud, E., Owais, W., AlRefae, K., \& Shahwan, Y. (2014). The Results of Applying the Principles of Corporate Governance in Corporations Listed on the First Market in the Amman Stock Exchange. Research Journal of Finance and Accounting, 5(14), 41-53. Available at: https://www.researchgate.net/publication/282974333 The Results of_Applying the Principles_of_Corpora te Governance in Corporations_Listed on the First_Market in the Amman_Stock_Exchange

8. Al-Sufy, F. J., Almbaideen, H. I. M., Al-abbadi, H. M., \& Makhlouf, M. H. (2013). Corporate governance and its impact on the quality of accounting information in the industrial community shareholding companies listed in Amman financial market-Jordan. International Journal of Humanities and Social Science, 3(5), 184-189. Available at: http://www.ijhssnet.com/journals/Vol 3 No 5 March 2013/18.pdf

9. Berle, A. A., \& Means, G. C. (1932). The Modern Corporation and Private Property. New Jersey, Transaction Publishers. Available at: https://andrewdsmith.files.wordpress.com/2017/01/berle-and-meanssthe-modern-corporation-and-private-property-for-upload-jan-2017.pdf

10. Buallay, A., Hamdan, A., \& Zureigat, Q. (2017). Corporate governance and firm performance: evidence from Saudi Arabia. Australasian Accounting Business and Finance Journal, 11(1), 78. Available at: https://ro.uow.edu.au/aabfj/vol11/iss1/5/

11. Das, P. (2014). The role of corporate governance in foreign investments. Applied Financial Economics, 24(3), 187-201. Available at: https://ideas.repec.org/a/taf/apfiec/v24y2014i3p187-201.html

12. Fogarty, T. J., \& Rogers, R. K. (2005). Financial analysts' reports: an extended institutional theory evaluation. Accounting, Organizations and Society, 30(4), 331-356. Available at: https://econpapers.repec.org /RePEc :eee:aosoci:v:30:y:2005:i:4:p:331-356

13. Horngren, C. T. (1978). Implications for accountants of the uses of financial statements by security analysts. New York, Ayer Co Pub. Available at: https://www.amazon.com/Implications-AccountantsStatements-Development-contemporary/dp/0405109407 
Financial Markets, Institutions and Risks, Volume 4, Issue 1, 2020 ISSN (online) - 2521-1242 ISSN (print) - 2521-1250

14. Habbash, M. (2014). The impact of corporate governance and ownership structure on voluntary disclosure in annual reports of Saudi listed firms. Accounting Research, Saudi Accounting Association (SAA), 13(1), 58-96. Available at: https://ageconsearch.umn.edu/record/301151/files/201909292343 20_BEH_2019 _Vol15_Issue2_OS-Habtoor_et_al_Impact_corporate_ownership_325-356.pdf

15. Habbash, M., \& Alghamdi, S. (2015). The perception of earnings management motivations in Saudi public firms. Journal of Accounting in Emerging Economies, 5(1), 122-147. Available at: https://www.deepdyve.com/lp/emerald-publishing/the-perception-of-earnings-management-motivations-insaudi-public-QPuK2pvv0A

16. Hamdan, A. M., \& Al-Sartawi, A. M. (2013). Corporate governance and institutional ownership: Evidence from Kuwait's financial sector. Jordan Journal of Business Administration, 9(1), 1-26. Available at: http://www.academia.edu/28501833/Corporate_Governance_and_Institutional_Ownership_Evidence_from Kuwaits_Financial_Sector

17. Hermalin, B. E., \& Weisbach, M. S. (1998). Endogenously chosen boards of directors and their monitoring of the CEO. The American Economic Review, 88 (1), 96-118. Available at: https://econpapers.repec.org/RePEc:aea:aecrev:v:88:y:1998:i:1:p:96-118

18. Hermalin, B. E., \& Weisbach, M. S. (2003). Boards of directors as an endogenously determined institution: A survey of the economic literature. Economic Policy Review-Federal Reserve Bank of New York, 9, 6-26. Available at: http://faculty.haas.berkeley.edu/hermalin/601herma.pdf

19. Htay, S. N. N., MOHD SAID, R \& Salman, S. A. (2013). Impact of corporate governance on disclosure quality: Empirical evidence from listed banks in Malaysia. International Journal of Economics \& Management, 7(2), 242-279. Available at: http://www.ijem.upm.edu.my/vol7no2/bab04.pdf

20. Ioana, A. N. G. H. E. L., \& Mariana, M. A. N. (2014). Study regarding the impact of the audit committee characteristics on company performance. Studies in Business and Economics, 9(2), 5-15. Available at: https://ideas.repec.org/a/blg/journl/v9y2014i2p5-15.html

21. Jensen, M., \& Meckling, W. (1976). Theory of the firm: Managerial behavior, agency costs and ownership structure. Journal of Financial Economics, 3(4), 305-360. Available at: https://www.sciencedirect.com/ science/article/pii/0304405X7690026X

22. Jensen, M. C., \& Meckling, W. H. (1994). The nature of man. Journal of Applied Corporate Finance, 7(2), 4-19. Available at: https://papers.ssrn.com/sol3/papers.cfm?abstract id=5471

23. Larcker, D., \& Tayan, B. (2011). Corporate governance matters. 1st ed. New Jersey, FT Press. Available at: http://ptgmedia.pearsoncmg.com/images/9780132180269/samplepages/013218026X.pdf

24. McKinsey \& Company, J. (2002). Global investor opinion survey-Key findings. Available at http://www.eiod.org/uploads/Publications/Pdf/II-Rp-4-1.pdf

25. Merag, H., \& Adam, H. [معر اجو آدم]. (2012). Toward effective institutional governance to control earnings management in the finance section in Algeria. Conference on Corporate Governance as a Mechanism in Limiting Corruption. Available at: http://computersystemsartists.net/Syrian/programs/lookup/vocabulary-ar.txt

26. OECD (2004). OECD Principles of Corporate Governance. Paris, OECD Publishing. Available at: http://www.oecd.org/corporate/ca/corporategovernanceprinciples/31557724.pdf

27. Salehi, M., Moradi, M., \& Paiydarmanesh, N. (2017). The effect of corporate governance and audit quality on disclosure quality: Evidence from Tehran Stock Exchange. Periodica Polytechnica Social and Management Sciences, 25(1), 32. Available at: https://pp.bme.hu/so/article/view/8354

28. Umm Kulthum, N., AbdulLatif, B., \& Asmaa, K. (2014). The role of the board of directors in activating corporate governance at the level of economic institutions. Available at: https://pmb.univsaida.dz/busegopac/doc_num.php?explnum_id=103

29. Watson, S., \& Hirsch, R. (2010). The link between corporate governance and corruption in New Zealand. New Zealand Universities Law Review, 24(1), 42-74.

30. Yalamov, T., \& Belev, B. (2002). Corporate governance: An antidote to corruption-examples/lessons learned in Bulgaria and transition countries. Corporate Governance: An Antidote to Corruption, CIPE, 33-36. 